\title{
燐酸鹽皮膜形成法に關する研究*
}

$$
\text { 三好泉**北野勇** }
$$

\section{Studies on the Phosphate Film Formation on Steel Plates}

\author{
Izumi Miyoshi**, Isamu Kitano**
}

\begin{abstract}
s
(1) We made researches and experiments to find out working conditions which affect anticorrosion under phosphate film formation on steel plates.

(2) We found relation between grain sizes of crystals shown on phosphate film and working condition.
\end{abstract}

(3) We gathered data in respect to the same working conditions mentioned above which are applied.

\section{1. 前おき}

鉄鋼の防蝕法としての燐酸塩芚膜形成法はパーカライ ジング又はボンデライジングとして知られ自動車, 自転 車, 電気機器等に於て塗装下地として広く用いられ, 又 初期磨耗減少の目的たピストンリングや紡績機械部品等 にも利用されている。

筆者等ふふ此の方法を煙草機械（煙草紙巻機，煙草包装 機) 部品, ディーゼル機関部品, 電気冷蔵庫外函, 治工 具類等の洤装下地として利用するに当り，その防蝕力そ 支配するる作業条件, 生成した結晶の状態を確認し, 併せ て生産作亲に当つて発生方る種々の障害の対策を立てる 為に基礎婜験と応用実験とを試みた。

\section{2. 基礎賔 驗}

\section{(1) 処理液の主成分}

処理液は下記主剤を3\% 水浴液としたものて主珴 $\mathrm{A}$, Bは 3:1 の割合に混合するのを標隼とし, 此の割合に 混ぜた白色粉末が甫販せら猄最近は濃厚水溶液としたも のも売出されている。

主剂 $\left\{\begin{array}{lr}\text { A. 第一㶴酸マンガン } & \mathrm{Mn}\left(\mathrm{H}_{2} \mathrm{PO}_{4}\right)_{2} \cdot \mathrm{mH}_{2} \mathrm{O} \\ \text { B. 第一燐酸鉄 } & \mathrm{Fe}\left(\mathrm{H}_{2} \mathrm{PO}_{4}\right)_{2} \cdot \mathrm{nH}_{2} \mathrm{O}\end{array}\right.$

上記 $\mathrm{A}, \mathrm{B}$ を混合した場合の処理法をパーカライジン グと称するが，塗装下地の迅速法として知られているボ ンデライジングは, 上記 $(\mathrm{A}+\mathrm{B})$ に第一燐酸銅 $\mathrm{Cu}\left(\mathrm{H}_{2}\right.$ $\left.\mathrm{PO}_{4}\right)_{2} \cdot \mathrm{xH}_{2} \mathrm{O}$ (主風 $\mathrm{C}$ とす) を $(\mathrm{A}+\mathrm{B}): \mathrm{C}=6: 1$ に混

* 昭和 26 年 6 月 1 日, 金属表面技術協会第 3 回講 潌大会 (於東京) に発表

** 中日本重工業株式会社神戸造船所 (Kôbe Shipyard \& Engine Works, Central Japan Heavy Industries Ltđ, Kôbe)
合したものである。

又東北大学遠藤彥造博士 ${ }^{(1)}$ の報告によ机ば, 第一辚酸 互鉛 $\mathrm{Zn}\left(\mathrm{H}_{2} \mathrm{PO}_{4}\right) \cdot \mathrm{y} \mathrm{H}_{2} \mathrm{O}$ (主郕 $\mathrm{D}$ とす) を用い, $\mathrm{A}: \mathrm{D}=$ $3: 1$ とすることにより結晶䊀か微細化し, 又との防蝕力 か飛躍的に向上するとのことである。

\section{(2) 主成分の反応}

処理液の主成分は鉄鋼に対し鼻知の如く次の反応を行 い，鉄鋼表面に結晶状の不溶性化合物皮膜 $\left[\mathrm{mMnHPO}_{4}\right.$. $\mathrm{nFeHPO} \mathrm{H}_{4} \cdot(\mathrm{m}+\mathrm{n}) \mathrm{H}_{2} \mathrm{O}$ に $\mathrm{mMn}_{3}\left(\mathrm{PO}_{4}\right)_{2}, \mathrm{nFe}_{3}\left(\mathrm{PO}_{4}\right)_{2}$ 娄 混入した組成をもつ]

$$
\begin{aligned}
& \mathrm{Fe}+2 \mathrm{H}_{3} \mathrm{PO}_{4}=\mathrm{Fe}\left(\mathrm{H}_{2} \mathrm{PO}_{4}\right)_{2}+\mathrm{H}_{2} \cdots \cdots \cdots(1) \\
& \mathrm{Fe}+\mathrm{Fe}\left(\mathrm{H}_{2} \mathrm{PO}_{4}\right)_{2}=2 \mathrm{FeHPO}_{4}+\mathrm{H}_{2} \cdots \cdots \cdots \text { (2) } \\
& \mathrm{Fe}\left(\mathrm{H}_{2} \mathrm{PO}_{4}\right)_{2} \underset{\text { 冷却 }}{\stackrel{\text { 熱 }}{\rightleftarrows}} \mathrm{FeHPO}_{4}+\mathrm{H}_{3} \mathrm{PO}_{4} \cdots \cdots \cdots \text { (3) } \\
& \mathrm{Fe}+2 \mathrm{FeHPO}_{4}=\mathrm{Fe}_{\mathrm{d}}\left(\mathrm{PO}_{4}\right)_{2}+\mathrm{H}_{2} \quad \ldots \ldots \cdots(4) \\
& \mathrm{Fe}+\mathrm{Mn}\left(\mathrm{H}_{2} \mathrm{PO}_{4}\right)_{2}=\mathrm{MnHPO}_{4}+\mathrm{FeHPO}_{4}+\mathrm{H}_{2} \text { (5) } \\
& 3 \mathrm{Fe}+6 \mathrm{MnHPO}_{4}=\mathrm{Fe}_{3}\left(\mathrm{PO}_{4}\right)_{2}+2 \mathrm{Mn}_{3}\left(\mathrm{PO}_{4}\right)_{2} \\
& +3 \mathrm{H}_{2} \ldots \ldots \ldots \ldots \ldots \ldots \ldots \ldots \ldots \ldots \ldots \ldots \text { (6) }
\end{aligned}
$$

(3) 試 㖃 片

表面積 $10 \mathrm{~cm}^{2}$ の軟鋼板を試片とした。

\section{(4) 試験用妱理液}

市販品の外, マンガン, 鉄, 西铅, 潾酸の含有量の大 小ぶ皮膜形成に攻ぼす影響を調べる為に下記種々の夜を 調製した。

$$
\begin{aligned}
& \text { A夜 }\left\{\begin{array}{cr}
\text { 燐 酸 } & 25 \mathrm{~g} \\
\text { マンガン } & 5 \mathrm{~g} \\
\text { 水 } & 1 l
\end{array}\right. \\
& \text { B液 }\left\{\begin{array}{lr}
\text { 燐 酸 } & 15 \mathrm{~g} \\
\text { 電 解 } & \text { 鉄 } \\
\text { 水 } & 3.75 \mathrm{~g} \\
& 1 l
\end{array}\right.
\end{aligned}
$$

C 夜 市販ボンデライトパウダーを使用

（1）遠藤彥造, 日本金属学会誌， 10(1947)，3， 


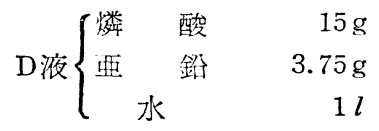

E液 市販パーカライジング用主剤を使用

(5) 舁験装置

$100 \mathrm{cc}$ ビーカ中に試験片をガラスフックにより鬃吊し た。又耐蝕試験に当つては $300 \mathrm{cc}$ ガラスビーカ中に $3 \%$ 食塩水を入れ処理後の試験片をガラスフックに上り浸漬

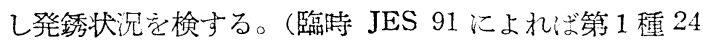
時間, 第 2 種時間となつている)。

（6）遊離潾酸量の決定

從来パーカライジングに於ては「全橓酸量」( $\left.\mathrm{C}_{\mathbf{T}}\right)$ と 「遊離潾酸量」( $\left.\mathrm{C}_{\mathrm{F}}\right)$ との比を 7.5 としたときが最良と 言われている。

$\mathrm{C}_{\mathrm{F}}=$ 処理液 $10 \mathrm{cc}$ を中和すべき $N / 10 \mathrm{KOH}$ の cc 数 (指示薬メチルオレンデ)

第1図全燐酸 $\left(\mathrm{C}_{\mathrm{T}}\right)$ 之遊離燐酸 $\left(\mathrm{C}_{\mathrm{F}}\right)$ との比の影響
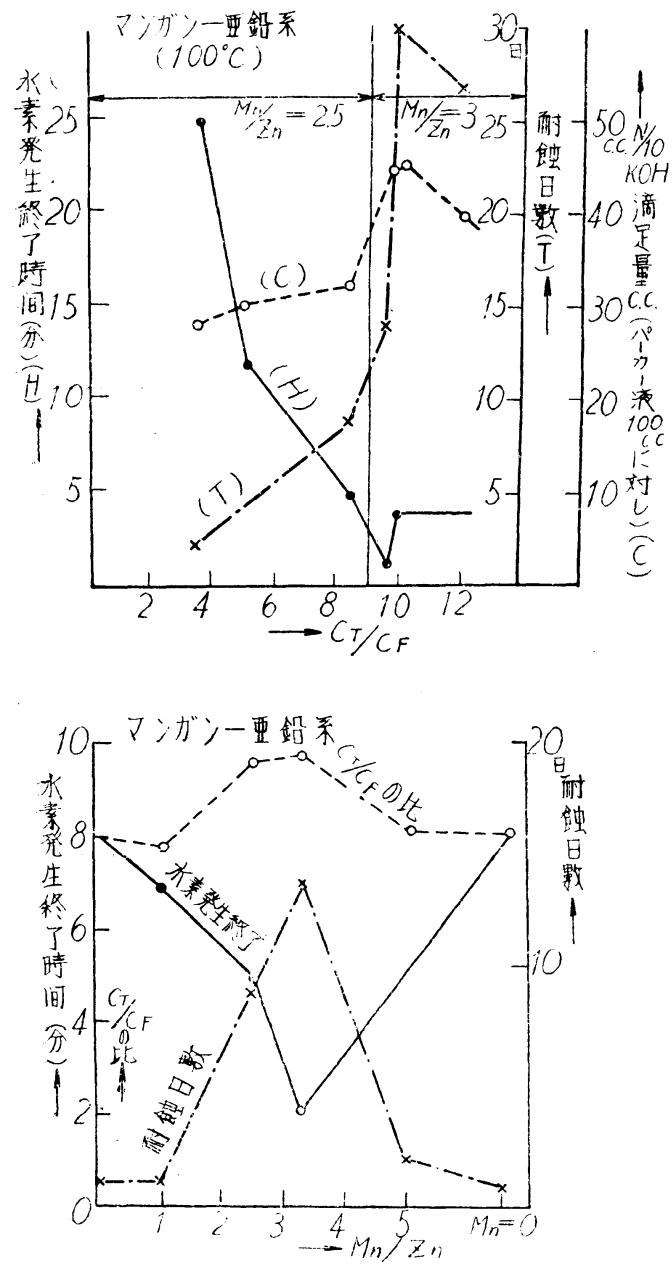

第3図 $\mathrm{Mn} / \mathrm{Zn}$ 比の影響
$\mathrm{C}_{\mathrm{T}}$ 二引続き加光ら叔た $N / 10 \mathrm{KOH}$ のcc数（指示蕌 フエフルフタレン)

筆者等の央験結果は第 1，2 表文び第 1，2 図に示子 通で8.5〜11.0汸最良で品つた。

第 1 表 マンガン西㫟法

\begin{tabular}{|c|c|c|c|c|c|c|c|}
\hline $\begin{array}{l}\text { マン } \\
\text { ガン } \\
\text { 画鉛 } \\
\text { 比 }\end{array}$ & $\begin{array}{l}\text { 遊離 } \\
\text { 粼酸 } \\
N / 10 \\
\mathrm{KOH} \\
\mathrm{cc}\end{array}$ & $\begin{array}{c}\text { 全燐酸 } \\
\text { N/10 } \\
\mathrm{KOH} \\
\mathrm{cc}\end{array}$ & $\begin{array}{l}\text { 全 } \\
\text { 燐酸 } \\
\text { 遊離 } \\
\text { 燐酸 }\end{array}$ & $\begin{array}{l}\text { 水素 } \\
\text { 発生 } \\
\text { 終了 } \\
\text { 茫 } \\
\text { (分) }\end{array}$ & $\begin{array}{c}\text { 温度 } \\
{ }^{\circ} \mathrm{C}\end{array}$ & $\begin{array}{l}\text { 耐能期 } \\
\text { 間発鈈 } \\
\text { 氾 }(日)\end{array}$ & 外䚇 \\
\hline 2.5 & 6.2 & 21.9 & 3.5 & 25 & 100 & $2 \sim 1$ & 鼠色 \\
\hline$" \prime$ & 5.0 & 25.0 & 5.0 & 12 & " & $4 \sim 1$ & " \\
\hline "I & 3.5 & 29.4 & 8.4 & 5 & " & $6 \sim 9$ & 灭色 \\
\hline 3.0 & 4.2 & 40.3 & 9.6 & 2 & "I & & \\
\hline$"$ & 4.1 & 40.9 & 10.0 & 4 & "I & 30 & \\
\hline "I & 3.2 & 37.3 & 11.7 & 4 & " & 27 & 双点 \\
\hline
\end{tabular}

第 2 図全憐酸 $\left(\mathrm{C}_{\mathrm{T}}\right)$ と遊離憐酸 $\left(\mathrm{C}_{\mathrm{F}}\right)$ との比の影響
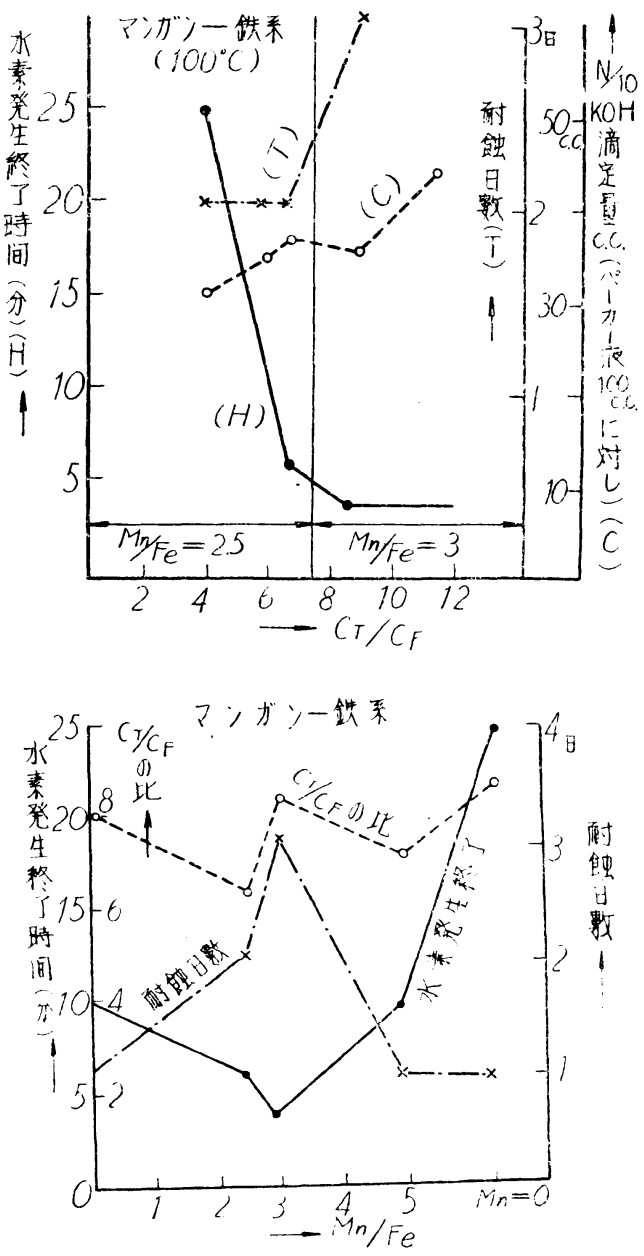

第4図 $\mathrm{Mn} / \mathrm{Fe}$ 比の影響 
第 2 表 マンガン鉄法

\begin{tabular}{|c|c|c|c|c|c|c|c|}
\hline $\begin{array}{l}\text { マン } \\
\text { ガン } \\
\text { 鉄の } \\
\text { 比 }\end{array}$ & $\begin{array}{c}\text { 遊離 } \\
\text { 燐酸 } \\
N / 10 \\
\mathrm{KOH} \\
\mathrm{cc}\end{array}$ & $\begin{array}{c}\text { 全燐酸 } \\
10 / N \\
\mathrm{KOH} \\
\mathrm{cc}\end{array}$ & $\frac{\text { 全 }}{\text { 憐酸 }}$ & $\begin{array}{l}\text { 水素 } \\
\text { 発生 } \\
\text { 終了 } \\
\text { 迄 } \\
\text { (分) }\end{array}$ & $\begin{array}{c}\text { 温度 } \\
{ }^{\circ} \mathrm{C}\end{array}$ & $\begin{array}{l}\text { 酎飿期 } \\
\text { 間発銹 } \\
\text { 迄 (日) }\end{array}$ & 外観 \\
\hline 2.5 & 6.8 & 23.8 & 3.5 & 25 & 100 & $2 \sim 1$ & 黑色 \\
\hline " & 5.2 & 28.6 & 5.5 & 12 & "I & "I & "I \\
\hline "I & 4.9 & 31.4 & 6.4 & 6 & "I & "I & "I \\
\hline 3.0 & 3.6 & 40.2 & 11.0 & 4 & "I & 3 & 厕色 \\
\hline "I & 3.7 & 31.4 & 8.5 & 4 & "I & $3 \sim 2$ & 鼠色 \\
\hline
\end{tabular}

(7) 主剤の比

マンガン一鉄, マンガン一覀鉊の比について防蝕力最 良の場合を求めた。第 $3 ， 4$ 表及び第 3，4図が之であ る。即ち, 共に $3: 1$ がよい。

第 3 表 $\mathrm{Mn} / \mathrm{Zn}$ 比の影響

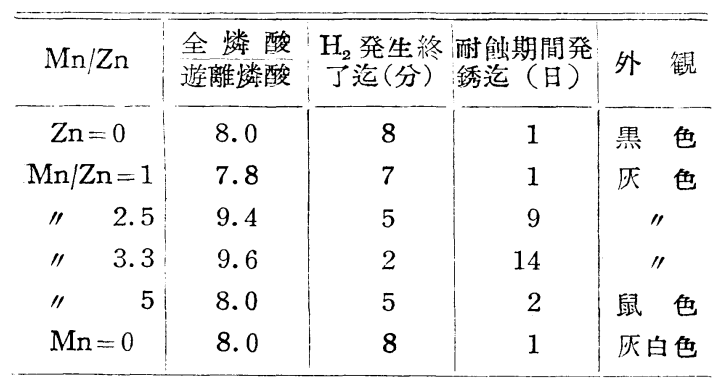

第 4 表 $\mathrm{Mn} / \mathrm{Fe}$ の比の影響

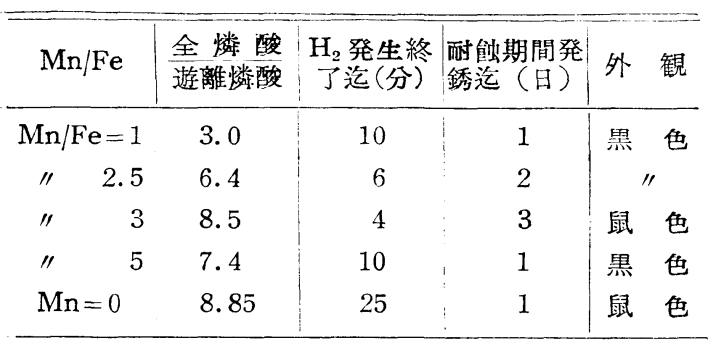

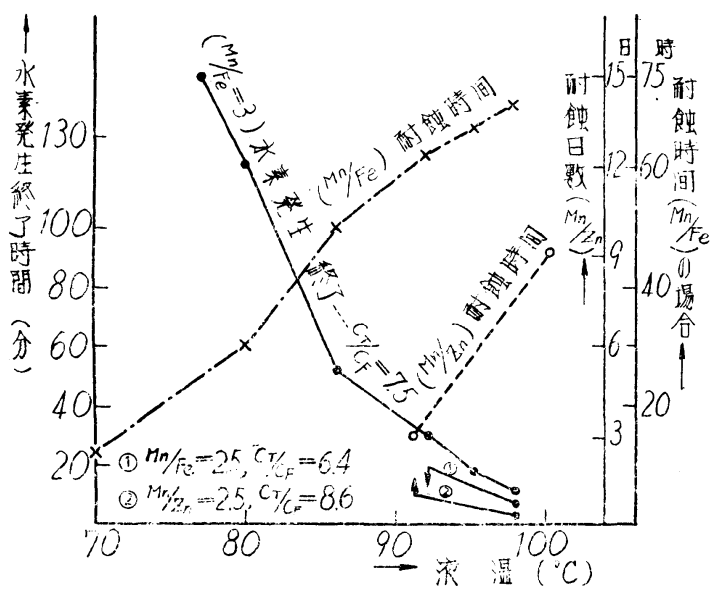

第5図液温の影響
(8) 液温

$70 \sim 100^{\circ} \mathrm{C}$ に亘つて耐蝕力最良の点を求內た 第 5.6 表文び第 5 図に示寸通り沸腾状態が最主である。

第 5 表 温度の影響 $\mathrm{Mn} / \mathrm{Zn}$

\begin{tabular}{|c|c|c|c|c|}
\hline $\mathrm{Mn} / \mathrm{Zn}$ & $\begin{array}{l}\text { 全 燐 酸 } \\
\text { 遊離燐酸 }\end{array}$ & ${ }^{\circ}{ }^{\circ} \mathrm{C}{ }^{\text {度 }}$ & $\begin{array}{l}3 \% \text { 食程水 } \\
\text { 中耐触期間 }\end{array}$ & $\begin{array}{c}\mathrm{H}_{2} \text { 発生終 } \\
\text { 了迄(分) }\end{array}$ \\
\hline 2.5 & 8.6 & $100^{\circ} \mathrm{C}$ & 6〜9日 & $5 \sim 5$ 分 \\
\hline " & $\|$. & $92^{\circ} \mathrm{C}$ & $2 \sim 3$ 日 & 15〜10分 \\
\hline
\end{tabular}

第 6 表 温度の影響 $\mathrm{Mn} / \mathrm{Fe}$

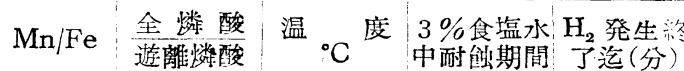

\begin{tabular}{|c|c|c|c|c|c|}
\hline 2.5 & 6.4 & $100^{\circ} \mathrm{C}$ & 2 日 & 6 分 & \\
\hline "I & "I & $93^{\circ} \mathrm{C}$ & $2 \sim 1$ 日 & $15 \sim 20$ & 11 \\
\hline 3 & 7.5 & $100^{\circ} \mathrm{C}$ & 70 時間 & 10 & " \\
\hline " & "I & $97^{\circ} \mathrm{C}$ & $67 \prime \prime$ & 18 & " \\
\hline "I & "I & $93^{\circ} \mathrm{C}$ & $63 \prime \prime$ & 30 & "I \\
\hline "I & " & $86^{\circ} \mathrm{C}$ & $50 \prime \prime$ & 52 & " \\
\hline " & " & $80^{\circ} \mathrm{C}$ & $30 \prime \prime$ & 120 & " \\
\hline " & " & $70^{\circ} \mathrm{C}$ & & $180 " 1$ & 以上 \\
\hline
\end{tabular}

\section{(9) 液の濃度}

$3 \%$ 水浴液が標準であるが 1〜5\% に亘つて笑験した 結果も第 7,8 表肢び第 6 図に示与通り $3 \sim 4 \%$ が最息 であつた。

第 7 表 液の濃度の影锌

\begin{tabular}{|c|c|c|c|c|}
\hline $\mathrm{Mn} / \mathrm{Zn}$ & $\mathrm{g} / 100 \mathrm{cc}$ & $\begin{array}{l}\text { 全 燐酸 } \\
\text { 遊離燐.酸 }\end{array}$ & $\begin{array}{l}\mathrm{H}_{2} \text { 発生絈 } \\
\text { 了范(分) }\end{array}$ & $\begin{array}{c}\text { 耐䘅期閐 } \\
\text { (日) }\end{array}$ \\
\hline 3 & 3 & 8.4 & 4 & 6 \\
\hline " & 5 & 8.0 & 3 & 4 \\
\hline
\end{tabular}

（10）反復使用に於ける液成分の变化

処理液 1 立に付 $300 \mathrm{~cm}^{2}$ の処理每に $5 \%$ 宛濃度が低

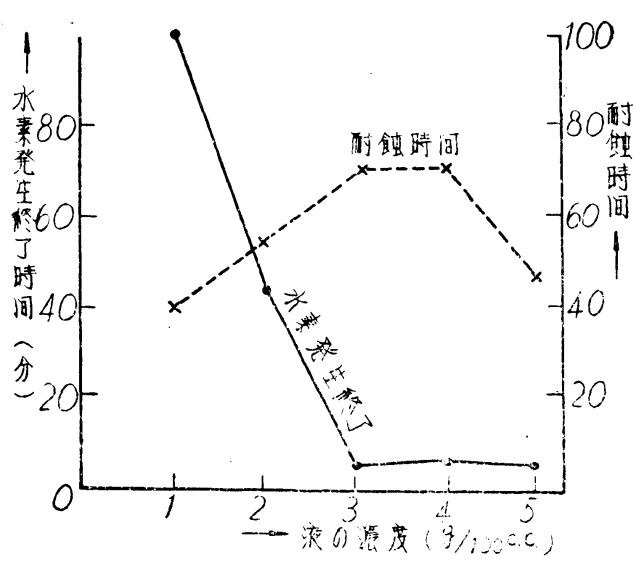

第 6 図液の濃度の影響 
第 8 表 液の濃度の影響

\begin{tabular}{|c|c|c|c|c|}
\hline $\mathrm{Mn} / \mathrm{Fe}$ & $\mathrm{g} / 100 \mathrm{cc}$ & 全燐酸 & $\frac{\mathrm{H}_{2} \text { 発生終 }}{\text { 了迄(分) }}$ & $\begin{array}{c}\text { 耐饳期間 } \\
\text { (時) }\end{array}$ \\
\hline 2.5 & 1 & 8.0 & 100 & 40 \\
\hline " & 2 & " & 45 & 55 \\
\hline " & 3 & " & $5 \sim 10$ & 70 \\
\hline " & 4 & "I & 7 & 70 \\
\hline " & 5 & " & 4 & 48 \\
\hline
\end{tabular}

下すると言うが，100 cc の液に対し $10 \mathrm{~cm}^{2}$ の試験片を 2 回浸清処理した結果第 9,10 表の上 5 に耐蝕力低下と $\mathrm{C}_{\mathrm{r}} / \mathrm{C}_{\mathrm{F}}$ 比低下が認められ，1立に対し $200 \mathrm{~cm}^{2}$ 処理铕 に液の調製をはかる要があると考える。

第 9 表 反復使用に於ける全燐酸，遊陮橉酸の变化

\begin{tabular}{|c|c|c|c|c|c|c|}
\hline $\mathrm{Mn} / \mathrm{Zn}$ & 回 数 & $\frac{\text { 全燐酸 }}{\text { 遊離:燐酸 }}$ & $\begin{array}{l}\text { 遊離: } \\
\text { 燐酸 }\end{array}$ & 全燐酸 & $\begin{array}{l}\mathrm{H}_{2} \text { 発 } \\
\text { 生終了 } \\
\text { 迄(分) }\end{array}$ & $\begin{array}{c}\text { 耐能性 } \\
\text { (日) }\end{array}$ \\
\hline 3 & 処理前 & 11.9 & 3.2 & 37.3 & & \\
\hline " & 1 回後 & 9.0 & 4.3 & 38.7 & 6 & 6 \\
\hline "I & 2 回後 & 7.5 & 5.8 & 43.5 & 6 & 5 \\
\hline
\end{tabular}

第 10 表 反復使用に於ける全燐酸, 遊離燐酸の变化

\begin{tabular}{|c|c|c|c|c|c|c|}
\hline $\mathrm{Mn} / \mathrm{Fe}$ & 回 数 & $\left|\frac{\text { 全燐酸 }}{\mid \text { 遊離燐酸 }}\right|$ & $\begin{array}{l}\text { 遊離 } \\
\text { 憐酸 }\end{array}$ & 全燐酸 & $\begin{array}{l}\mathrm{H}_{2} \text { 発 } \\
\text { 生終了 } \\
\text { 迄(分) }\end{array}$ & $\begin{array}{l}\overline{\text { 耐蝕性 }} \\
\text { (日) }\end{array}$ \\
\hline 3 & 処理前 & 11.0 & 3.63 & 40.2 & & \\
\hline "I & 1 回後 & 8.2 & 4.31 & 35.3 & 6 & 1 \\
\hline "I & 2 回後 & 6.7 & 5.0 & 33.7 & 6 & 1 \\
\hline
\end{tabular}

（11） 水素発生終了時間

上記の各笂験に於て共通して言い得ることは水素発生 終了時間と耐蝕性が反比例していることで時間の短い程 完全な皮膜が出来ていることが認められる。

（12）ボンデライト法の耐蝕性

C液，E液を用い上記と同様の耐蝕試験を行つたが， その結果は第 11 表の通で耐蝕性が劣るが水素発生終了 時間短、迅速作業によいこと犬゙認的られた。

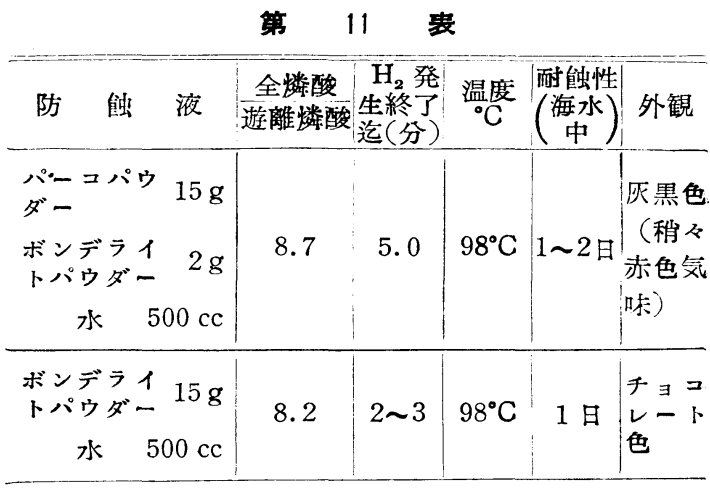

\section{3. 皮膜表面の顯微錤的觀察と作業 時間との關係}

第 12 表汇示すような条件で処理したものの頙微鏡管 真を示すと，写真第 1〜6 の通である。

写真から判断すると，

(1)ボンデライジング法の結晶はパーカライジング法 に比べさい（結晶粒の大さ 2/1000 10/1000 饿標準)

(2)パーカライジングの標準結晶は 10/1000〜20/1000 粍と思预机る。

(3)水素発生終了時間を超過して処理を継続すると結 晶が著しく成長し長さに於て数倍になり, 又との生長す る結晶も不均一で従つて鉄鋼表面に大きな山四凸を作るこ とが肉眼でも判別出来る。従つてこのような場合には耐 蝕力も低下寸るから作業に当つては水素発生終了後に浸 清を継続してはならないことがわかる。

\section{4. 實際作業に於ける液の管理}

(1) 作業順序

第 7 図に示す方法で行つた。

(2) 前 処 理

脱脂後の酸洗:さ塩酸が硫酸より良好であるが，酸洗後 充分水洗し更に予熱に上り化成槽液温の低下を防止与 る。

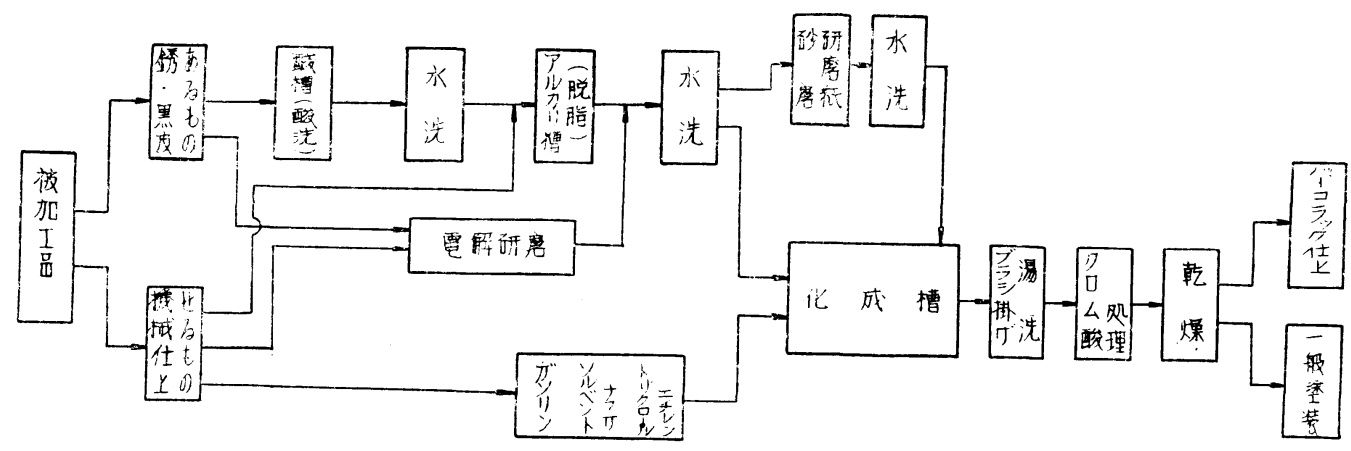

管 7 図作業工程 
（3）液の管理の為の測 定事項

6 ケ月に亘り毎日次の項 目について測定し, これに 応じて液の修正を行つた。 その結果は第 8 図に示す通 りである。(化成槽容量 30 立のものにつき記す)

(1) 毎日のパウダー添加 量…前日の処理面積に応 じて追加する, 実際には下 記(2)(4)の測定結果に基き添 加する。

(2) 液比重 (基準 $\mathrm{d}_{\mathbf{4}}^{15}=$ 1.0175)

(3) $\mathrm{C}_{\mathrm{r}} / \mathrm{C}_{\mathrm{F}}$ 比

(4) $N / 10 \mathrm{KOH}$ 滴定量 cc $\left(\mathrm{C}_{\mathrm{T}}+\mathrm{C}_{\mathrm{F}}\right) \cdots$ この和が 主㓮の $g / l$ を示す。

(5) 水素発生終了時間.. ・基䂾実験より多くなり 20 〜30 分となる。

(6) 耐蝕時間……每日数 個の試験片を品物と共に処 理し，その耐蝕時間を測定 する。

\section{5. 化成槽に生ず る沈澱㳯の再生}

化成槽に於ては品物と液 の反応により不溶性の燐酸 塩を（2～6）式の如く生じ 皮膜が形成せられるが，こ の反応生成物は液中でも生 じヌマンガンが品物の鉄分 と置換消費されるので液中 のマンガンは減少する一方 であり, 反面鉄は増加を続 ける。 $\mathrm{MnHPO}_{4}, \mathrm{Fe} \mathrm{HPO}_{4}$ の水に対する溶解度は小で

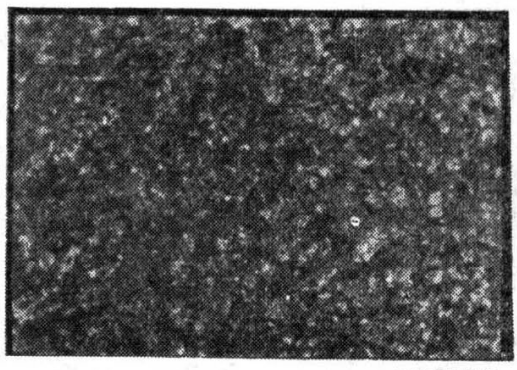

$\times 500$
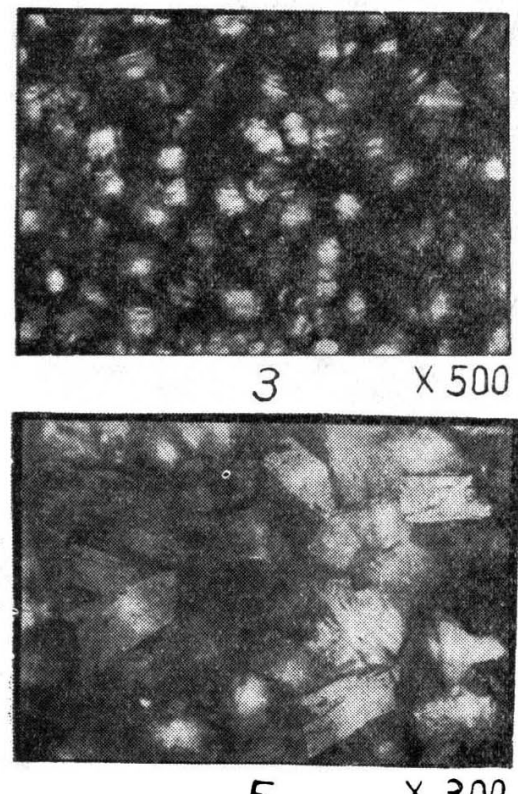

5
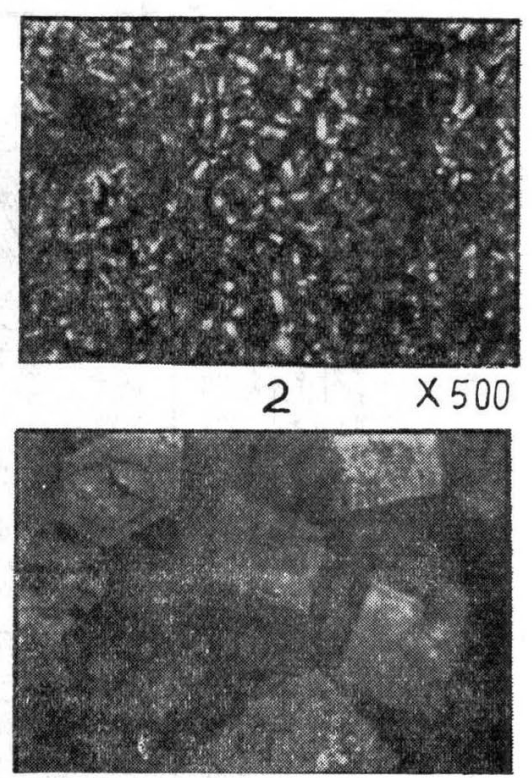

$4 \times 300$

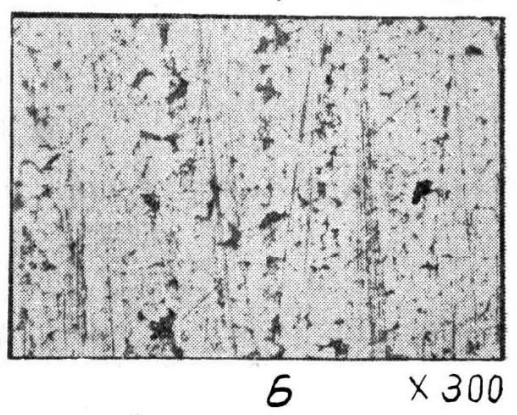

$6 \times 300$

第 12 表 写真 説 明

\begin{tabular}{|c|c|c|c|c|c|c|c|c|c|}
\hline $\begin{array}{l}\text { 写真 } \\
\text { 番号 }\end{array}$ & 化 & 片 & $\begin{array}{c}\text { 全燐 } \\
\text { 酸量 } \\
\mathrm{C}_{\mathrm{N}} \mathrm{cc}\end{array}$ & $\begin{array}{l}\text { 遊 離 } \\
\text { 燐酸量 } \\
\mathrm{C}_{\mathrm{FCC}}\end{array}$ & $\mathrm{C}_{\mathrm{T}} / \mathrm{C}_{\mathrm{F}}$ & $\begin{array}{l}\text { 处理 } \\
\text { 時間 }\end{array}$ & $\begin{array}{c}\mathrm{H}_{2} \\
\text { 発生終 } \\
\text { 了時間 }\end{array}$ & 液 温 & 外 \\
\hline 1 & C & $30 \mathrm{~g} / l$ & 25.2 & 3.3 & 7.6 & 2 分 & 2 分 & $100^{\circ} \mathrm{C}$ & $\begin{array}{l}\text { チョコレー } \\
\text { ト色微結晶 }\end{array}$ \\
\hline 2 & $\begin{array}{l}\mathrm{C} \\
\mathrm{E}\end{array}$ & $\begin{array}{r}27 \mathrm{~g} / \mathrm{l} \\
3 \mathrm{~g} / \mathrm{l}\end{array}$ & 26.5 & 3.4 & 7.8 & 5 分 & " & " & $\begin{array}{l}\text { 量 褐 色 } \\
\text { 微 結 晶 }\end{array}$ \\
\hline 3 & $\mathrm{E}$ & $30 \mathrm{~g} / l$ & 25.8 & 3.4 & 7.6 & 3 分 & 3 分 & " & 巵色滑 か \\
\hline 4 & 同 & 上 & " & "I & " & 10分 & " & " & $\begin{array}{l}\text { 灰色散乱面 } \\
\text { 結 晶 粗 }\end{array}$ \\
\hline 5 & 同 & 上 & "I & "I & " & 30分 & " & "I & $\begin{array}{l}\text { 灰色散乱面 } \\
\text { 結 晶 粗 }\end{array}$ \\
\hline 6 & 無处理( & 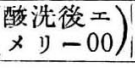 & & & & & & & 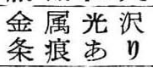 \\
\hline
\end{tabular}

ある為, 沈㸡となつて品物表面に附着して作業の妨害と むなり, 又主剤の損失ともなる。一般に品物の皮膜形成 に消費される量の 10 倍以上が沈澱漳となるもので，こ の再生除去は此の種作業上極めて重要である。

筆者等は沈澱滓を分析した結果

$\begin{array}{ll}\mathrm{MnHPO}_{4} & 10 \sim 20 \% \\ \mathrm{FeHPO}_{4} & 70 \sim 50 \%\end{array}$

の場合が多いので次の処置をとつた。

（1）沈澱㳯を集めこれを燐酸（10７0\%）に溶解し 溶解完了後にマンガンを沈洀の 2 倍以上添加し，これを 原液として毎朝補給する。

（2）化成液中の $\mathrm{Mn} / \mathrm{Fe}$ の比も小さくなつているか ら（1）の方法がとれない時には下記の再生剤を每期混入 し, 液の温度上算過程中に沈澱滓を溶解したり, 液の各 


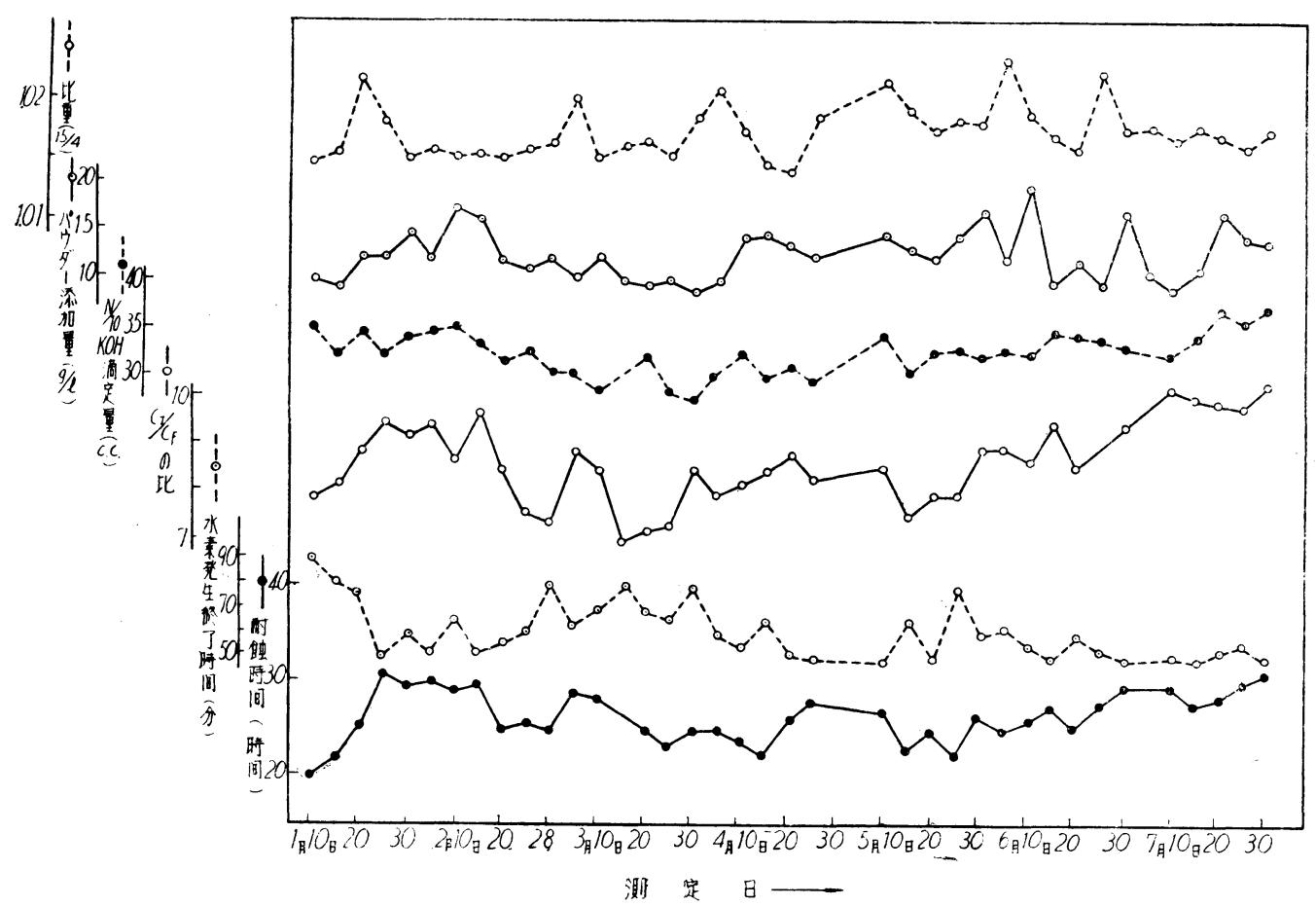

第 8 図作業状況之处理条件

種条件を標準状態にるつてくる方法をとる。

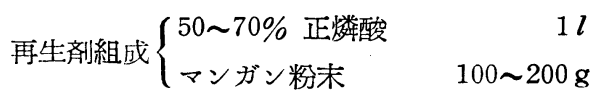

(3) 上記( 2 )の方法によつて $\mathrm{C}_{\mathrm{F}} / \mathrm{C}_{\mathrm{F}}$ 比が過小であ れば鎑華によつて中和し標準状態にする。

以上の方法によつて艋日の作業を順調に保ち且つ耐食 力大なる面を得, 作業能率も向上した。

\section{6. 結言}

（1）燐酸塩皮膜形成法に於ての或分，作業条件等が

反応終了時間, 及び皮膜耐蝕性に改ぼす影響につき笑験 した。

（2）生成した皮膜の顕微鏡写真により反応終了後も 処理を継続すると，結晶粒が急激化生長して巨大とな门 その分布不均一で，耐蝕力が低下ずることを壦めた。

（3）実際作業に於ては基礎実験の俻項目について䇠 日測定して液の修正と標準化を行い，又大量に生成する 沈源㳯の溶解再生により主剤の節約を行つた。

- - (昭和 26 年 10 月 20 日受理) -

\section{メタリコン加エ品の硫酸 銅試驗}

武井 武* 長坂 秀雄

\section{The Preece Test (Copper Sulphate Dip) for Sprayed Zinc Coating on Iron.}

Takeshi Takei, Hideo Nagasaka, Kazuko Inugai

Fundamental studies about the Preece test for the spraye $\mathrm{d}$ zinc coatings on iron were carried out in order to ascertain whether this test is adoptable in J.I.S. or not.

From the results of several experiments, it was concluded that the Preece can be adopted in J.I.S. as in the case of galvanized zinc coating with nearly the same monual. But in the case of sprayed 